\title{
Öğrenci Katılımına Zemin Hazırlayan Etkileşimsel Bir Kaynak: Eksik Tasarlanmış Sözceler*
}

\section{An Interactional Resource for Creating Opportunities for Student Participation: Designedly Incomplete Utterances}

\author{
Nergiz KARDAŞ İŞLER ${ }^{1} \quad$ Ali Ekber ŞAHIN ${ }^{2} \quad$ Ufuk BALAMAN $^{3}$ \\ - Geliş Tarihi: $10.09 .2018 \bullet$ Kabul Tarihi: 07.11.2018 • Yayın Tarihi: 01.01.2019
}

\section{$\ddot{O} \mathbf{z}$}

Bu çalışma, ilkokul sosyal bilgiler dersindeki sınıf içi etkileşimi inceleyerek, öğretmenlerin öğrenci katılımını sağlama amacı ile kullandığı bir etkileşimsel kaynağı betimlemeyi amaçlamaktadır. Sosyal bilgiler sınıfları multidisipliner eğitsel ortamlar olup, zengin içeriklerin öğretiminin gerçekleştirilmesini gerektirmektedir. Bu tür etkinliklerin gerçekleştirilmesi ise öğrenci katılımının sağlanması ile doğrudan alakalıdır. Ancak bu konuda sosyal bilgiler alanında herhangi bir çalışma yapılmamış ve öğrenci katılımı, katılımın gerçekleşme anlarına odaklanmayan çalışmalarla anlaşılmaya çalışılmıştır. Çalışmamız, ilkokul sosyal bilgiler sınıf içi etkileşimini, Konuşma Çözümlemesi yöntemini kullanarak 17 saatlik bir veri bütüncesi içerisinde incelemiş ve öğretmenin, öğrenci başlatımlarını teşvik etme ve öğrenci katılımına zemin hazırlama amacıyla, tekrarlı olarak bir etkileşimsel kaynağa başvurduğunu ortaya koymuştur. Bu etkileşimsel kaynak, Eksik Tasarlanmış Sözce (ETS) olarak alanyazında da yer almış ve öğretmenin sözceleri eksik tasarlayarak, öğrencilerin tamamlamasına olanak sağladığı ve böylece öğrenci katılımına zemin hazırladığı tespit edilmiştir. Çalışmamızın bulguları, öğretmenin ETS'leri; 'önceki öğrenmeyi hatırlatma', 'konuşmanın genişletilmesi', 'önceki konuşmaların tekrarını alma' ve 'eylemin devamına teşvik' amacıyla etkileşime dahil ettiğini göstermiştir. Böylelikle öğretmen, öğrenci başlatımlarını ve katkılarını teşvik ederek, katılımı artırmayı başarmış ve öğrenme firsatlarının ortaya çıkmasını sağlamıştır. Çalışmamız, sosyal bilgiler alanına, yöntemsel bir yenilik getirmekte, alandaki sınıf içi etkileşim çalışması eksiğini gidermekte ve öğretmen ve öğretmen adaylarına, öğrenci katılımını sağlamak üzere zengin bir etkileşimsel kaynak örneği sunmaktadır.

Anahtar sözcükler: Sosyal bilgiler, sınıf içi etkileşim, konuşma çözümlemesi, eksik tasarlanmış sözce, öğrenci katılımı

\section{Önerilen Atıf Bilgisi:}

Kardaş İşler, N., Şahin, A.E.. ve Balaman, U.(2019). Öğrenci katılımına zemin hazırlayan etkileşimsel bir kaynak: Eksik tasarlanmış sözceler. Pamukkale Üniversitesi Eğitim Fakültesi Dergisi, 45, 376396.

\footnotetext{
*Bu çalışma, birinci yazarın Hacettepe Üniversitesi, Eğitim Bilimleri Enstitüsü’nde tamamladığı doktora tezine dayanmaktadır.

${ }^{1}$ Arş. Gör., Hacettepe Üniversitesi, Eğitim Fakültesi, ORCID:: 0000000295361428 n.kardas@ hacettepe.edu.tr

${ }^{2}$ Prof. Dr., Hacettepe Üniversitesi, Eğitim Fakültesi, ORCID: 0000000237289982 alisahin@ hacettepe.edu.tr

${ }^{3}$ Dr. Öğr. Ü., Hacettepe Üniversitesi, Eğitim Fakültesi, ORCID: 0000000150929414 ubalaman@ gmail.com
} 


\begin{abstract}
This study examines social studies course classroom interaction in a primary school and describes an interactional resource deployed by the teacher for creating opportunities for student participation. Social studies classrooms are multidisciplinary settings that require teaching of rich content, which is only possible through ensuring student participation. However, there is no study to our knowledge that documents such resources in social studies classrooms by focusing on the micro moments of classroom interaction. This study investigates 17 hours of social studies classroom interactions using Conversation Analysis as the research methodology and present findings on a specific interactional resource deployed repeatedly by the teacher for encouraging learner initiatives and creating opportunities for student participation. This resource has been referred to in previous literature as Designedly Incomplete Utterance (DIU) that is mainly used for creating opportunities for student participation by leaving an utterance designedly incomplete so that it can be completed by the students. Our study has shown how designedly incomplete utterance (DIU) is used as an interactional resource (i.e. as hints, for eliciting an extension or repetition of prior talk, and for prompting the continuation of an action) by the teacher, which provides evidence for that the teacher creates opportunities both for student initiations and student participation in an observable way. Our study contributes to the field of social studies education with the first research to examine social studies classroom interaction and also by presenting an innovative research methodology and providing the teachers and teacher candidates with a rich interactional resource to encourage, create opportunities for, and maintain student participation. Keywords: Social studies, classroom interaction, conversation analysis, designedly incomplete utterance, student participation
\end{abstract}

\title{
Giriş
}

Sosyal bilgiler dersi ilkokul düzeyinde vatandaşlık, hukuk, tarih, coğrafya, ekonomi, sosyoloji, felsefe, antropoloji, sanat tarihi ve siyaset bilimi gibi değişik alanlarda öğrencilere çeşitli katkılarda bulunan önemli bir derstir. Diğer birçok derste olduğu gibi bu dersin de öğrenme ortamlarındaki temel unsurlardan birisi öğrenci katılımıdır. Newmann'a göre (1992) katılım, öğrenci başarısızlığı gibi birçok yaygın bilinen problemin üzerinde, öğrenme öğretme süreçlerinin en önemli problemidir. Öğrencilerin derse katılımı, öğretmenin olumlu bir sınıf ortamı yaratması ve öğrencilerle kurulan etkileşimle gerçekleşebilir (Allwright, 2005; Sert, 2017). Sınıf içi etkileşim, tek boyutlu, istikrarlı ve durağan bir uygulama dizisi değildir. Çoklu bağlamların ortaya çıkması ve pedagojik olayların birlikte yapılandırılması için katılımcı yönelimlerini temel alan; karmaşık, dinamik ve değişken bir müzakereler dizisidir (Seedhouse, 2004; Sert, 2015; Walsh, 2006). Bu temelde sınıf içi etkileşimsel süreçlerin, öğrenme öğretme etkinliklerine nasıl dahil olduğu önemli bir inceleme konusu olarak eğitimin farklı alanlarında ele alınmıştır.

Yöntemsel açıdan, sınıf içi etkileşim ile ilgili ilk çalışmalar, kodlama şemaları kullanarak etkileşimin gözlemlenmesi ve tanımlanmasına odaklanırken, son yıllarda giderek artan bir şekilde konuşma çözümlemesi yöntemini (Sert, Balaman, Can Daşkın, Büyükgüzel, Ergül, 2015) temeline alan ve sınıf içi etkileşimin mekaniğini inceleyen çalışmalar önem kazanmıştır. Türkiye bağlamında ise sınıf içi etkileşimi inceleyen çalışmalar yabancı dil sınıfları üzerine yoğunlaşmış ve okul öncesi (Balaman, 2018), lise (Bozbıyık, 2017; Sert, 2015; 2016; 2017) ve üniversite (Badem, 2018; Can Daşkın, 2015, 2017; Sumruk, 2018) dil sınıflarını inceleyen konuşma çözümlemesi çalışmaları alanyazına kazandırılmıştır. Yine bu kapsamda fen sınıfları (Kaya, 2017), öğretmen yetiştirme sinıfları (Duran, 2017) ve çalışmamıza temel olan ilkokul sosyal bilgiler sınıfları (Kardaş İşler, 2019) üzerine de sınıf içi etkileşim araştırmaları bulunmaktadır. Dolayısıyla ülkemizde son yıllarda konuşma çözümlemesi yöntemi kullanılarak gerçekleştirilen sınıf içi etkileşim çalışmalarındaki artışın, önemli bir tarihsel altyapı temelinde (Ingram, Briggs, \& Johnston-Wilder, 2011; Margutti ve Drew, 2014; McHoul, 1978, Seedhouse, 
2004; Sert, 2015; Skovholt, 2018; Waring, 2016; Zemel ve Koschmann, 2011) dünyadaki benzer örneklerle aynı doğrultuda ilerlediğini iddia etmek mümkündür.

Sınıf içi etkileşim, sosyal bilgiler dersinin yürütülmesinde de önemli bir unsurdur (Kardaş İşler, 2019). Sosyal Bilgiler dersinin genel odağı insan davranışıdır ve dersin tüm bileşenleri geçmişte ve günümüzde bireylerin birbirileriyle ve çevreleriyle nasıl etkileşimde bulunduğuyla ve hangi yollarla örgütlenip, yönetildiğiyle ilgilenmektedir (Welton-Malian, 1999). Bu kapsam aynı zamanda iletişim, sosyal katılım ve Türkçeyi doğru, güzel ve etkili kullanma becerilerini (MEB, 2005) de içeren ve dolayısıyla derse katılımın dersin başarısında temel bir unsur olduğu etkileşimsel bir ortama işaret etmektedir. Türkiye'de sosyal bilgiler dersi ile ilgili yapılmış çalışmalar incelendiğinde, çalışmaların yoğunlukla benzer çerçevelerde yürütüldügü ve bunların sınıflardaki süreci etkileşim anlarına dayanan kanıtlarla ifade etmediği görülmektedir. İlkokul düzeyinde ve sosyal bilgiler dersi gibi etkileşimi merkezine alan bir dersin, öğrenme öğretme süreçlerini içeren etkileşimsel verilerle henüz incelenmemiş olması, ilgili alanyazında önemli bir boşluk olarak değerlendirilmiş ve bu çalışma ile bu boşluğun doldurulmasına katkıda bulunulması hedeflenmiştir. Dolayısıyla çalışma, katılımın artırılması gibi temel bir probleme yönelik araştırma bulgularına dayanan çözümler ortaya koyacak ve sosyal bilgiler eğitimi alanına bir araştırma yöntemi sunarak ilgili çözümlerin devamlı olarak kazandırılmasına aracılık edecektir.

$\mathrm{Bu}$ temelde, bu çalışmanın amacı, ilkokul dördüncü sınıf sosyal bilgiler dersinde tüm sınıf etkileşimi kapsamında ortaya çıkan öğrenci başlatımlarında sıklıkla görülen eksik tasarlanmış sözcelerin (ETS) öğrenci katılımına olan etkisini konuşma çözümlemesi yöntemi ile betimlemektir. Çalışmamız, bir ilkokul sınıfının sosyal bilgiler dersi ortamındaki etkileşimsel desenlerinin mikro detaylarını sunmasından dolayı özgün bir nitelik taşımaktadır. Araştırma çıktılarıyla sınıf öğretmenlerinin ve sınıf öğretmeni adaylarının sosyal bilgiler derslerinde öz değerlendirme de yapabilecekleri gerçek bir sınıf ortamındaki etkileşimsel yapı ve desenler ortaya koyulacaktır. İlkokul sosyal bilgiler dersindeki öğrenci katılımlarının detaylı ve ayrıntılı bir betimlemesi; öğrencilerin gelişimlerini destekleyici öğrenme ortamlarının tasarlanmasına ve Eksik Tasarlanmış Sözceler gibi etkileşimsel kaynakların öğrenci katılımına etkisini ortaya çıkarmaya olanak tanıyacaktır. Bu amaçla, takip eden bölümlerde öncelikli olarak; sınıf içi etkileşime odaklanılarak etkileşim kapsamında gerçekleşmesi hedeflenen öğrenci katılımının temel bir kavramı olan öğrenci başlatımları üzerine bir alanyazın taraması sunulacak ve hemen ardından yine öğrenci katılımını artırmak üzere kullanılan eksik tasarlanmış sözceler detaylarıyla açıklanacaktır. $\mathrm{Bu}$ bölümler aracılığıyla sunulan araştırma çıktılarına dayalı kavramsal temel, sırasıyla yöntem, analiz ve bulgular ve sonuç ve tartışma bölümlerine de bilimsel altyapı sağlayacaktır.

\section{Öğrenci Katılımını Sağlama Ekseninde Öğrenci Başlatımları ve Eksik Tasarlanmış Sözceler}

\section{Öğrenci başlatımları}

İlgili çalışmayla katkıda bulunulacak sınıf içi etkileşim alanı üzerine daha önce edinilmiş bulgular sınıflardaki öğretmen merkezli etkileşimlerde, öğretmenin konuşma dizisini başlattığı, öğrencinin karşl1ık verdiği ve öğretmenin bir şekilde üçüncü söz sırasını (örneğin bir değerlendirme ile) alarak konuşma dizisini tamamladığı örneklere sıklıkla işaret etmektedir. Sınıf etkileşimi, öğrenme firsatlarını kolaylaştırmada önemli bir rol oynar. Bu öğrenme firsatları sadece öğrencilerin dil kullanımı bilgisini (söz dizimi, kelime bilgisi, telaffuz ve söylem) değil 
aynı zamanda etkileşime nasıl katıldığını da içerir. Bu bağlamda, sınıflarda öğrencilerin başlatımları etkileşimsel açıdan temel bir role sahiptir. Sert (2017) öğrenci başlatımlarının etkili bir biçimde yönetilmesinin öğrenme firsatları açısından da önemli olduğundan bahsetmiştir. Yine Paoletti ve Fele'ye (2004) göre de, öğrenme firsatları oluşturmada öğrenci başlatımlarının öğrenci katılımını kolaylaştıran değeri sıklıkla gözlemlenmiştir. Bu kapsamda öğrenci katılımını arttıran temel bir unsur olarak öğrenci başlatımları, sosyal bilgiler sınıfları açısından da merkezi bir öneme sahiptir (Kardaş İşler, 2019).

Öğrenci başlatımları üzerine kapsamlı çalışmasında Waring (2011), hangi öğrenci başlatımlarının, öğrenmeyi desteklediğini ve öğrenci katılımını arttırmayı sağladığını incelemiştir. $\mathrm{Bu}$ inceleme kapsamında öğrenci başlatımlarının öz seçim (self selection), yani öğrencinin söz sırasını alma girişiminde bulunmasının ötesinde bir etkileşimsel kaynak olduğunu ve kendine özgü bir tipolojiye sahip olduğunu ortaya koymuştur. Öğrenci başlatımları, söz sırası alma ve dizi düzeni (bkz. Yöntem) gibi iki temel etkileşimsel boyutta değerlendirilerek anlaşılabilmektedir. Öğrenci başlatımları ile öğrenci katılımı arasındaki yadsınamaz etkileşimsel ilişki, öğretmenlerin öğrenci başlatımlarını teşvik edecek ve ortaya çıkmasına aracı olacak etkileşimsel kaynaklar kullanmasında da önemli bir rol oynamıştır. Bu kapsamda öğrenci başlatımlarının gerçekleştiği konuşma dizilerinde, öğretmenlerin, eksik tasarlanmış sözceleri (designedly incomplete utterances, Koshik, 2002) sık kullanmaları da çalışmamıza temel olan bir bulgudur (Kardaş İ̧şler, 2019).

\section{Etkileşimsel bir kaynak olarak eksik tasarlanmış sözceler}

Yukarıda detayları sunulan temelde çalışmamız sosyal bilgiler sınıf içi etkileşimi üzerine bir konuşma çözümlemesi araştırması sunacak ve öğrenci başlatım anlarına yoğunlaşarak eksik tasarlanmış sözcelerin etkileşime nasıl dâhil edildiği ve sınıf içi etkileşim ilerleyişinde nasıl bir role sahip olduğu ortaya koyulacaktır. Bunu yaparken aynı zamanda sosyal bilgiler dersi öğrenme öğretme ortamlarında öğrenci katılımının artırılması açısından oldukça önemli bir kaynağı (eksik tasarlanmış sözceler) tasvir edecektir. Çalışmamız, sınıf içi etkileşim anlarının konuşma çözümlemesi yöntemiyle incelenmesi sonucunda edinilecek bulguları, kanıta dayalı bir biçimde ve eleştirel bir bakış açısıyla alana kazandırma hedefi de güdecektir. Eksik tasarlanmış sözceler farklı kavramlar altında çeşitli çalışmalarda ortaya koyulmuştur. İlk olarak Mehan (1979) tarafından "soru şeklindeki bir cümleyi tamamlama yapısı" olarak adlandırılmıştır. Lerner (1995), bu yapıları daha detaylı inceleyerek bunlara "eksik söz sırası oluşturma birimleri” adını vermiştir. Daha sonra ise Koshik (2002) bu yapıyı "eksik tasarlanmış sözceler (designedly incomplete utterances)" olarak kavramlaştırmış ve alandaki bütün araştırmacıların mutabık kaldığı bir kavramı çeşitli etkileşimsel boyutlarıyla kapsamlı bir çalışma aracılığıyla sunmuştur.

Koshik (2002), bu sözcelerin, öğrencinin sahip olduğu bilgiyi ortaya çıkarmak için kullanılan bir söz sırası tipi olduğunu, sözdizimsel bir soru ya da tamamlanmış bir söz sırası oluşturma birimi olmadığını ve eksik olacak şekilde tasarlandığı için adının "Designedly Incomplete Utterance (DIU)" olduğunu belirtmektedir. Bu terim; Türkçe'ye Sert (2016) tarafindan "Eksik Tasarlanmış Sözce (ETS)" olarak çevrilmiştir. Koshik (2002), ETS’ler üzerine öğretmenin eksik söz sıralarını herhangi bir iletişim zorluğundan dolayı değil, aksine, 
farkındalıkla, eksik olarak tasarladığını ve buradaki amacın öğrencilere bu eksik sözceleri ${ }^{4}$ tamamlama görevini vererek katılım sağlama olduğunu ifade etmektedir. Margutti (2010) ise, ETS'yi öğretmenler tarafından kullanılan ve sözceyi tamamlayan kısımdaki eksik bilgileri ortaya çıkarmanın bir aracı olarak görmektedir. Netz (2016) de ETS'deki dilbilgisel olarak eksik olan öğenin, tek bir hece veya bir sözcük gibi küçük birimlerden, bir tümcecik veya tam bir tümce gibi daha büyük birimlere varan bir çeşitliliğe sahip olabileceğini belirterek ETS çalışmalarına katkıda bulunmuştur. Etkileşimsel düzen açısından ETS; öğretmen tarafından üretilen, dilbilgisi kurallarına uygun olarak tamamlanmamış bir söz sırası oluşturma birimidir (SOB) ve sıralı çiftin ilk kısmı (first pair part) olarak öğretim dizilerinin bir parçası şeklinde kullanılan etkileşimsel kaynaklardır. Öğretmenin SOB'un sonuna doğru ünlü sesleri uzatması ve SOB'yi yükselen tonlamayla sonlandırması ETS'lerin sesletimsel özelliklerini oluşturmaktadır (Koshik, 2002; Lerner, 1995; Margutti, 2010).

Koshik (2002), ikinci dil olarak İngilizce yazma derslerinde ETS'nin kullanımını incelerken, Margutti (2010) bir ilkokuldaki bütün sınıfla etkileşimde ETS'nin kullanımını incelemiştir. ETS'nin işlevi ile ilgili olarak Margutti'ye göre (2010), bir öğrenciden yanıt alma aracı olarak ETS, bilgiyi almanın yanı sıra öğrencilerin bilgisini kontrol etme, anahtar kavramları vurgulama, devam eden etkinlikte öğrencilerin katılımını sağlama, koruma ve sürdürme gibi sınıf içi öğretim düzeninde birçok farklı işlevi yerine getirmektedir. Netz (2016) ise ETS'nin kullanımını öğrenci katılımını sağlama ve sürdürme amaçlı, yaygın olarak kullanılan bir kaynak olduğunu ancak eksik tasarlanmış kısmın açık ve net olmamasının sınıf içi etkileşimi olumsuz etkileyebileceğine dikkat çekmiştir. Bunun yanı sıra anlaşılır ve açık bir biçimde öğrenciye yöneltilen ETS'lerin öğrenci katılımını arttırdığını da eklemiştir. Sıradan, günlük konuşmalarda ETS'ler daha çok tahmin edilebilir sözceleri tamamlama istekleri ya da kelime arama/anımsama anlarında kullanılırken, sınıf içi ortamlar gibi kurumsal konuşmalarda ETS pedagojik amaçlarla kullanılarak öğrenciye etkileşime dahil olma firsatı sunmakta ve öğrencinin sahip olduğu bilgiyi ortaya çıkarmayı amaçlamaktadır. Pedagojik bağlamlarda, Koshik (2002) ETS'nin dört temel kullanımını betimlemiştir: (1) ipucu olarak kullanılan ETS'ler (DIUs used contingently as hint), (2) daha önceki konuşmaların tekrarı için kullanılan ETS'ler (DIUs that elicit repetition of prior talk), (3) daha önceki konuşmaların genişletilmesi için kullanılan ETS'ler (DIUs that elicit an extension of prior talk) ve (4) eyleme devam edilmesinin teşviki için kullanılan ETS'ler (DIUs used as prompts to continue an action). Takip eden bölümdeki araştırma yöntemi ve araçları kullanılarak ETS'ler ilkokul sosyal bilgiler sınıflarında incelenecek ve betimlenecektir.

\footnotetext{
${ }^{4}$ Sözce, belli bir kişi tarafindan belli bir iletişim amacıyla oluşturulan bir dilsel üründür. Bir sözce ancak kullanıldığı bağlam ve durum içinde anlam kazanır ve tümcenin aksine, dilbilgisel açıdan doğru ya da tam olmayabilir. Tek bir sözcük bile sözce olabilir (Onursal, 2003).
} 


\section{Yöntem}

Çalışmanın bu bölümünde, araştırma deseninden ve veri toplama sürecinden bahsedilerek odaklanılan sosyal bilgiler sınıfı tanıtılacak ve Konuşma Çözümlemesi (KÇ) yöntemi temelinde, araştırmanın nasıl gerçekleştirildiği üzerine bilgiler sunulacaktır.

\section{Araştırma Deseni ve Veri Toplama Süreci}

Çalışmada, amaçlı örnekleme yöntemlerinden tipik durum örneklemesi kullanılmıştır. Patton'a göre (1987), "tipik durum örneklemesi ile amaç, ortalama durumları çalışarak belirli bir alan hakkında fikir sahibi olmak veya bu alan, konu, uygulama veya yenilik konusunda yeterli bilgi sahibi olmayanları bilgilendirmektir" (Akt. Yıldırım ve Şimşek, 2011). Bu çalışma çerçevesinde çalışmanın yürütüldüğü okulun, Milli Eğitim Bakanlığı Strateji Geliştirme Başkanlığı'nın örgün eğitim kurumlarının yayınladığı istatistiki bilgiler ışığında (2016) Ankara ili Çankaya ilçesinde bulunan diğer ilkokullar gibi öğretmen sayısı, derslik sayısı ve öğrenci sayısı açısından ortalama bir düzeye sahip olduğu görülmüştür. Bu nedenlerden dolayı seçilen okulun tipik, normal ve ortalama olanı gösterdiği düşünülmektedir. Veri toplama sürecinden önce Hacettepe Üniversitesi Senatosu Etik Komisyonu'na başvuru yapılarak 7 Temmuz 2015 tarihinde Etik Kurul Onayı alınmış daha sonra ise seçilen okulda veri toplanabilmesi için Milli Eğitim Bakanlığı'na başvuru yapılarak Ankara Valiliği Milli Eğitim Müdürlüğü’nden gerekli izin alınmıştır. Katılımcı grubunun 18 yaşın altında olması sebebiyle hem katılımcılardan hem velilerinden yazılı olarak onay alınmıştır. Çalışmanın verileri, 2015-2016 eğitim-öğretim yılının Eylül, Ekim ve Kasım ayları süresince Ankara'nın Çankaya ilçesindeki bir devlet okulunun dördüncü sınıf düzeyindeki sosyal bilgiler dersinden elde edilmiştir. Sınıfta 24 öğrenci bulunmaktadır. Sınıf kuralları ve rutinleri öğrenciler ve veliler tarafından bilinmektedir. Sınıf öğretmeni, derslerde teknolojiyi ve farklı öğretim yöntem ve tekniklerini etkin bir şekilde kullanmaktadır. Sosyal bilgiler dersi için kullanılan ders ve çalışma kitabı Milli Eğitim Bakanlığı'nın onayladığı bir yayınevi tarafından basılmış bir kitaptır. Çalışma süreci boyunca araştırmacı tarafından sınıfın düzenini bozmaya ilişkin hiçbir eylem söz konusu olmamıştır. Katılımcıların gizliliğini korumak amacıyla çevriyazılarda takma isim kullanılmıştır. Çevriyazıda herhangi bir soruna sebep olmaması için takma isimlerin asıl isimlerle aynı hecede olmasına özen gösterilmiştir. Öğretmen çevriyazıda "Öğr" olarak adlandırılırken, öğrencilere verilen takma isimlerin ilk üç harfi kullanılmıştır. Örneğin; Mehmet ismi çevriyazılarda "Meh" olarak gösterilmiştir. Bunun yanı sıra öğrencilerde toplu olarak konuşma oluştuğunda ise kişi adı olarak tüm öğrencileri temsilen "ÖÖ” takma adı kullanılmıştır. Bunların yanında okulun adının, bulunduğu bölgenin ya da katılımcılara ilişkin herhangi bir kişisel bilginin çevriyazıda açığa çıkarıcı bir biçimde verilmemesine özen gösterilmiştir.

Veri toplama sürecinde üç adet video kayıt cihazı kullanılmıştır. Kayıt cihazlarından biri sınıfın arkasına, tahtayı ve öğretmen masasını görecek şekilde, diğer ikisi sınıfın sağ ve sol köşesine yerleştirilmiştir. Katılımcıların sürece uyumlarını sağlamak ve "observer's paradox" (Labov, 1972) diye adlandırılan kayıt cihazlarının varlığından öğretmen ve öğrenci davranışlarının etkilenmesi riskine karşı çalışmanın ilk haftasında toplanan veri katılımcıların kayıt cihazlarına ve gözlemcinin varlığına alışmaları için analizlere dâhil edilmemiştir. Süreç sonunda, 17 ders saatlik veri toplanmıştır. Elde edilen veriler arasında herhangi bir eleme olmadan tüm veriler detaylı bir şekilde Gail Jefferson'ın (2004) çevriyazı sistemine (Ek-1) göre Transana programı kullanılarak yazıya dökülmüştür. 
Konuşma çözümlemesi çalışmalarının bulgularının geçerliliği ve güvenilirliği, kayıt kalitesine, transkriptlerin doğruluğuna ve grup veri oturumlarının rutin etkileşimine bağlıdır. Bir sonraki alt bölümde de detaylandırılacağı gibi, üzerine kurulduğu temeller sayesinde, konuşma çözümlemesi güvenilir ve geçerliği yüksek bir araştırma yöntemidir. Aynı verileri iki farklı araştırmacının farklı algılaması ve yorumlaması kaçınılmaz görünse de KÇ araştırmacılarının aynı veri üzerine aynı analizi yapmaları beklenmektedir. Bu kapsamda, çalışmamızda güvenirlik için analizci üçgenlemesi yapılmıştır. Verilerin çözümlenmesi aşamasında çoklu bakış açısını sağlamak adına yazarların yanı sıra HUMAN Araştırma Merkezi (www.human.hacettepe.edu.tr) veri oturumlarında farklı zamanlarda veri incelemeleri gerçekleştirilmiş ve konuşma çözümlemesi alanında uzmanlaşmış bir başka araştırmacının da birçok çözümlemeyi gözden geçirerek gerekirse yeniden çözümleme yaparak karşılaştırmalara olanak sağlayıp ortak karara varmaları sağlanmıştır.

\section{Konuşma Çözümlemesi Yöntemi}

Konuşma Çözümlemesi (Conversation Analysis), sosyoloji alanı içerisinde, budunyöntembilimin (ethnomethodology) bir alt kolu olarak Harvey Sacks, Emanuel Schegloff ve Gail Jefferson (1974) tarafından, etkileşimin düzenli ve sistematik bir yapıya sahip olduğunu ortaya koyma hedefinden doğmuştur. Daha sonra çeşitli alanlarda kullanımı sıklık kazanmış, veriye dayalı, kanıt temelli, katılımcıların içeriden bakış açıları (emic perspective) üzerine argümanlar kuran, herhangi bir teori veya varsayıma dayanarak etkileşimi anlamlandırmaya çalışmak yerine etkileşimi bizzat etkileşimin kendi içerisindeki dinamiklerle betimlemek üzere kullanılan bir araştırma yöntemidir. Her ne kadar yöntem sosyoloji alanı içerisinde doğmuşsa da etkileşimin yer aldığ bütün alanlarda Konuşma Çözümlemesi, analitik bir yöntem olarak yer bulmuştur. Eğitim alanı da yöntemin etkin olarak kullanıldığı başlıca alanlardan biri olmuş ve çeşitli eğitim öğretim ortamları ve konu, ders, içerik paylaşımı etkinlikleri bu yöntemle incelenmiştir. Türkiye'de de yöntem son yıllarda birçok çalışmaya altyapı sağlamış ve Türkçe'ye de bağımsız bir araştırma yöntemi olarak bütün araştırma araçlarıyla birlikte kapsamlı bir şekilde kazandırılmıştır (Sert vd., 2015).

KÇ, yöntemsel olarak, etkileşime giren katılımcıların birbirlerini nasıl anladıklarını sistematik bir biçimde betimlemek hedefini güderek anlamlandırma süreçlerine dair kanıtlar sunmaktadır. Sosyal etkileşim, bir katılımcının (Örn. öğretmen veya öğrenci) bir söz sırasıyla etkileşime katkı yapması ile başlamaktadır. Söz sıraları ise kendi içerisinde anlam ifade eden söz sırası oluşturma birimlerinden (SOB) oluşmaktadır. Bir katılımcının etkileşime kattığı söz sırası ikinci katılımcının katkısı için de zemin hazırlamakta ve aynı zamanda ilk katılımcının söz sırasının nasıl anlamlandırıldığına dair kanıtı da beraberinde getirmektedir. Söz sırası değişimleri ise geçişe uygun nokta (GUN) adı verilen ve SOB'lerin bittiği noktalarda ifade edilmektedir. Sacks, Schegloff ve Jefferson'ın (1974) alanın kurucu çalışması olarak da kabul edilen makalesinde; söz sırası alma süreçlerinin birbirini tekrar eden ve çeşitli bağlamlarda benzer şekilde ortaya çıkan desenlerle etkileşime katıldığı, kanıtlarla sunulmuştur. Dolayısıyla söz sırası alma, sosyal etkileşimin ve sosyal etkileşimle tamamlanan bütün sosyal eylemlerin temelini oluşturmakta ve anlamlandırma süreçlerini gözlemlemeyi araştırmacılar için mümkün kılmaktadir.

Birbirinin takip eden ve farklı katılımcılar tarafından etkileşime sokulan söz sıraları birbiriyle her zaman alakalıdır ve bu alaka sağlanamamışsa bu durum etkileşime duyma veya anlama sıkıntısı şeklinde yansıyabilmekte ve onarımı sağlanmadan etkileşimsel hedeflere 
ulaşılamamaktadır. Örneğin ilk katılımcı tarafından sorulan bir soru, ikinci katılımcı tarafından yanıtlanmakta ise birkaç gözlemlenebilir etkinlikten bahsetmek mümkündür. Öncelikle ilk katılımcı bir soru sorarak, ikinci katılımcıyı etkileşime dahil etmiş ve bir yanıt beklentisi bulunduğunu ortaya çıkarmıştır. Diğer taraftan ilk katılımcının söz sırasının bir soru olabilmesi, ikinci katılımcının buna yanıt verme yönelimiyle netlik kazanmıştır. Bu türden birbiriyle alakalı söz sıralarının farklı katılımcılar tarafından etkileşime dahil edilmesine dizi düzeni adı verilmektedir. Diziler, sorular gibi ilkler ve cevaplar gibi ikilerden oluşmakta ve bu yolla sıralı çiftler halinde sıralı çiftin ilk kısmı (SÇ1; örn. soru) ve sıralı çiftin ikinci kısmı (SÇ2; örn. yanıt) olarak sosyal etkileşimin söz sırası ile birlikte temelini oluşturmaktadır.

SÇ1'ler genellikle bir sosyal eylemin ortaya çıkışına da aracılık etmektedirler. Örneğin bir soru ile ikinci katılımcıya yönelik bir davet, bu katılımcıdan bir istekte bulunma veya sınıf içi etkileşim gibi kurumsal etkileşim ortamlarında öğretmenin öğrenciden (veya tam tersi) bir bilgi talebi gerçekleştirebilir. Bu türden sorular, davetse, davetin kabulü; istekse, isteğin yerine getirilmesi; bilgi talebiyse, bilginin verilmesi gibi ikinci katılımcının katk1 alanını da sınırlayarak, yeğlenen bir yanıta işaret etmekte ve böylece bir yeğleme düzenini etkileşime sokmaktadırlar. Dolayısıyla söz sıraları aracılığıyla etkileşime giren katılımcılar, dizi düzeni oluşturmakta ve bu düzen aynı zamanda bir yeğleme düzenine dair işaretleri de içerisinde barındırmaktadır. $\mathrm{Bu}$ düzeneğin içerisinde bir anlama ve duyma sorunu yaşandığındaysa, katılımcılar bu soruna yönelim göstererek etkileşimi onarmakta ve karşılıklı anlamayı sağlayarak etkileşimsel hedeflerine ulaşmaktadırlar.

Sosyal etkileşim söz sıralarının alındığı, verildiği, paylaşıldığı; birbiriyle alakası sağlanmış söz sıralarının soru-yanıt benzeri sıralı çiftler aracılığıyla dizisel düzenler oluşturduğu, bu düzenlerin içerisinde yeğleme düzeni aracılığıyla etkileşimsel hareket alanların belirlendiği, duyma/anlamı gibi sorunların onarımlar aracıllğıyla giderildiği ve bu türden ilerleyişlerin adeta zincirleme bir şekilde ve sürekli olarak birbiri ardına eklenmesi ve bu yolla katılımcıların birbirlerini anlaması olarak tanımlanabilir. Bu temelde, söz sırası alma, dizi düzeni, yeğleme düzeni ve onarım Konuşma Çözümlemesi'nin temel sosyo-analitik bileşenleri olarak kullanılmaktadır. Bu bileşenler aracılığıyla etkileşimin mikro temelleri, her bir SOB, GUN ve bütünüyle söz sıralarının birbirini takip eder bir biçimde, satır satır ve anbean incelenmesi ve bu yolla etkileşimin her bir anında katılımcıların anlamlandırmayı nasıl gerçekleştirdiklerinin ortaya çıkarılmasıdır. Katılımcıların bu süreçlerde kullandıkları etkileşimsel yöntemler aynı zamanda araştırmacının da edinebileceği bulgular olarak ele alınmaktadır. Böylece KÇ araştırmalarından edinilen bulgular, bizzat katılımcıların birbirlerini anlamak için kullandığı araçlardan başka bir şey olmayacaktır. Bu türden, içeriden bir bakış açısını (emic perspective) sağlayabilmek KÇ'nin sağlam temellere oturmuş bir araştırma yöntemi olarak ortaya çıkmasını ve on yıllardır artan bir biçimde kullanılmasını sağlayan temel unsurdur.

$\mathrm{Bu}$ yöntemsel altyapıyı kullanarak, KÇ araştırmacıları, araştırma süreçlerine doğal olarak gelişen etkileşim verilerini toplayarak başlarlar (bkz. Veri Toplama Süreci). Bunu takiben çevriyazılar ile görüntü ve ses kayıtlarının eş zamanlı ve çok tekrarlı incelenmesi yoluyla, güdüsüz inceleme (unmotivated looking) olarak da bilinen; herhangi bir araştırma fikrine sahip olmadan, veri temelli bir ilerleyişle etkileşim verilerinin incelemesi gerçekleştirilir. $\mathrm{Bu}$ süreçte göze çarpan olası vakalar ve etkileşimsel fenomenler detaylı transkriptler eşliğinde bütün bir veri tabanında tekrar eden örnekleri keşfetmek amacıyla daha yakından ele alınır. Tekrarlı bir ortaya çıkma söz konusu olabildiğinde, tekrarları içeren etkileşimsel fenomenlerden 
oluşturulan koleksiyonlar, veri temelli argümanlar oluşturmak için de sürecin başlaması anlamına gelmektedir. İlgili koleksiyonlara dayanan ve onları temsil eden kesitler, araştırma makalelerine ve/veya bilimsel raporlara dahil edilerek araştırma çıktıları diğer araştırmacılar ve özellikle eğitim alanında öğretmenler ve öğretmen adayları başta olmak üzere tüm paydaşlara açılır. $\mathrm{Bu}$ ilerleyiş doğrultusunda, çalışmamız $\mathrm{KÇ}$ çalışmalarının tüm gerekliliğini yerine getirmiş ve eksik tamamlanmış sözcelerin (ETS) veri bütüncesi içerisinde tekrarlı olarak ortaya çıktığ görülmüsstür. Takip eden bölümde ETS'lerin farklı türleri üzerine kesitler ve analizler sunulacak ve ilgili bulgular ve sonuçlar, tartışma bölümünde alanyazın ışığında tekrardan ele alınacaktır.

\section{Bulgular}

Çalışmamızın bu bölümünde, elde dilen bulgular ve sonuçlar dört ayrı bölümde sunulacaktır. Her bir bölüme detaylı çevriyazısı yapılmış konuşma kesitlerine ilişkin bilgilerle, önce konuşmanın geçtiği bağlam yani o anda sınıfta ne yapılmakta, işlenen konu nedir, öğretmen ne tür bir etkinlik gerçekleştirmektedir, dersin kaçıncı dakikasıdır ve konuşma dizisini ortaya çıkaran olay nedir sorularına cevaplar sunularak giriş yapılacaktır. Konuşmanın ortaya çıktığı bağlam kısaca anlatıldıktan sonra, konuşma dizilerine ait detaylı çevriyazılar kesitler halinde gösterilecektir. Daha sonra ise bu konuşma kesitleri, Konuşma Çözümlemesinin tüm analitik çerçeveleri açısından satır satır çözümlenecek ve bunu takiben Eksik Tasarlanmış Sözceler (ETS) açısından bulgular sunulacaktır. Elde edilen öncelikli bulgular; sınıf öğretmeni tarafından kullanılan ETS'nin farklı şekillerde ancak aynı pedagojik amaç olan bilgiyi ortaya çıkarma amacıyla kullanıldığını göstermiş ve farklı kullanım şekillerinin Koshik'in (2002) de belirttiği dört farklı şekille uyumlu olduğu ortaya çıkarılmıştır. Bu farklı ETS uygulamalarını temsili olarak gösteren dört konuşma kesiti, bulgular ve sonuçlar bölümünün de dört alt bölümü olarak aşağıda gösterilecektir.

\section{1.İpucu olarak kullanilan ETS'ler}

Haftanın ilk sosyal bilgiler dersidir. Öğretmen, farklı durumlara ait duygularını ve düşüncelerini ifade etme ve başkalarına saygı duyma kazanımlarını edindirmek için "Altı Şapkalı Düşünme Tekniğiı"ni uygulamayı planlar. Bu bağlamda şapkalarla ilgili açıklamalar yaparken sarı şapkanın iyimserliği temsil ettiğini söylemesi üzerine bir öğrenci “iyimser" sözcüğünün anlamını sorarak bir başlatım yapar. Bunun üzerine konuşulurken, öğretmen iyimserliği simgeleyen "Pollyanna" isimli hikâye karakterinin ismini öğrencilerden almaya çalışır. Bunu takiben dersin 15. dakikasında ortaya çıkan konuşma dizisi Kesit 1'de gösterilmiştir.

\section{Kesit 1. Pollyanna}

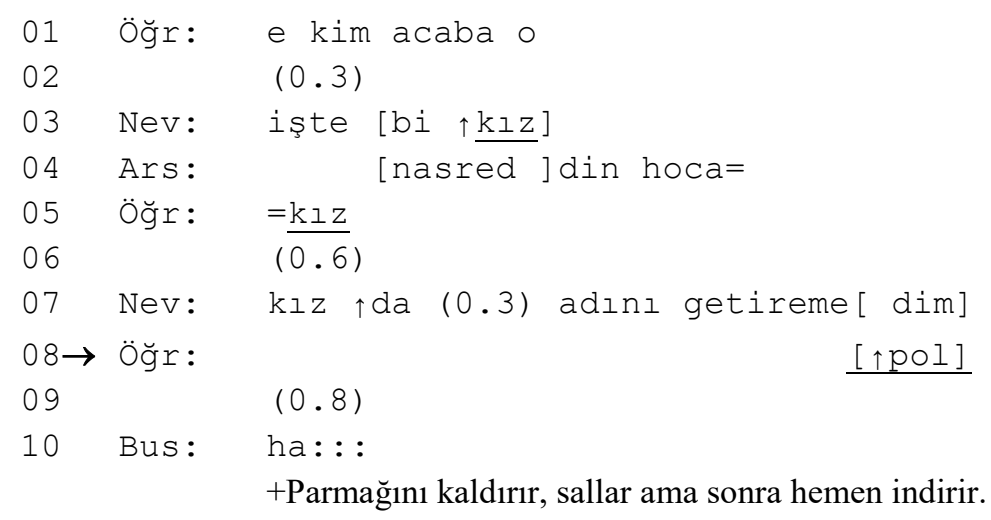




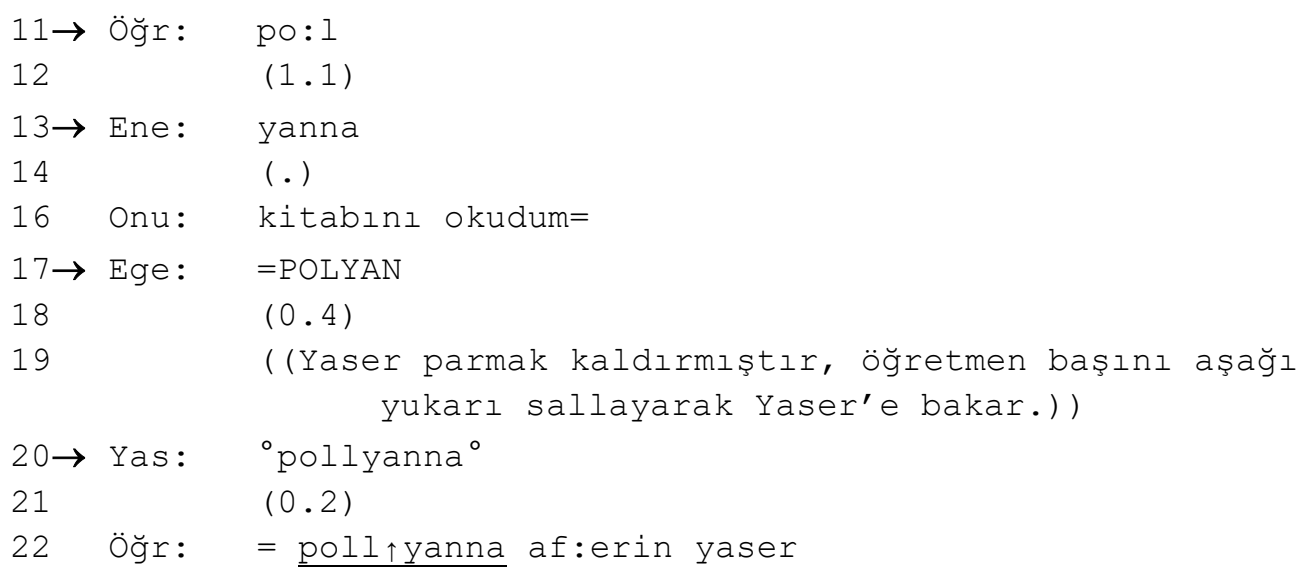

Kesit 1, öğretmenin Pollyanna karakteriyle ilgili sorularına satır 1'de "e kim acaba o" diyerek ve önceki öğrenci katkılarını da kullanarak yeni bir soruyla devam etmesiyle başlar. Daha sonra satır 3'te Nev'den ve satır 4'te Ars'tan örtüşme (overlap) içerisinde iki aday yanıt gelir. Öğretmenin Nev'den gelen yanıtı dikkate alarak satır 5 'te vurgulu bir şekilde " $k \_z$ " diyerek öğrenciyi tekrar etmesi ile onayladığı ve öğrenci katkılarının devam etmesini beklediği görülmektedir. Öğretmenin satır 5'teki kullanımı aynı zamanda Ars'ın katkısına yönelik bir onarım olarak duyulabilecek olsa da, ilerleyen satırlarda Ars'ın buna dair bir yönelimi ve de öğretmenin bakış veya vücut açısıyla Ars'a yönelimi bulunmadığından onarım olarak etkileşime dahil edilmediği iddia edilebilir. Öğretmenin söz sırasının kendisine yönelik olduğunu değerlendiren Nev, satır 7'de “adını getiremedim” diyerek yanıtı bildiğini ancak hatırlayamadığını belirtir. Sonrasında ise öğretmenin, öğrenci katkılarını devam ettirmek için satır 8'de doğru yanıt olan kahramanın adının ilk hecesini yükselen tonlama ile ( $\uparrow \underline{\underline{p o l}})$ der ve öğrencilere eksik tasarlanmış sözce ile bir ipucu verir. Bu durum ETS'nin önceki öğrenmeleri hatırlatmak için kullanılma işlevi (Sert \& Walsh, 2013) ile aynı doğrultudadır. Yine benzer şekilde, ETS'lerin öğrencilerin sözceyi şekillendirmek için katkı yapmalarını teşvik ettiği daha önce de (Margutti, 2010) gösterilmiştir. Satır 10'da Bus, bir durum değişikliği belirteci (ha: : :) ile yanıtı iletme isteğini söz sırasını almak üzere parmağını kaldırarak belirtmiş olsa da parmağını hemen indirir ve söz sırasını alamaz. Öğretmenin ilk ETS kullanımından sonra satır 11'de bir kez daha ETS kullandığı ve bu kez sesi uzatarak (po:1) farklı bir sesletimsel yapı içerisinde ETS'yi öğrencilere yönelttiği görülmektedir. 1.1 saniyelik bir sessizlikten sonra, sözcenin eksik kısmı, satır 13'te Ene adlı öğrenciden gelen "yanna” yanıtıyla tamamlanır ancak öğretmen bu yanıta bir yönelim göstermez. Sirasıyla satır 16'da gelen "kitabını okudum" ve satır 17'de gelen "POLYAN" yanıtlarına da yönelim göstermeyen öğretmen, satır 20'de parmak kaldırdıktan sonra söz verdiği Yas'ın ETS'nin tamamlanmış halini söylediği yanıtını kabul eder. Bunu takiben öğrenciye "af : erin” diyerek vurgulu olumlu değerlendirme (explicit positive assesment, Waring, 2008) yapar ve kesit sona erer.

Öğretmenin satır 8 ve satır 11'deki kullandığı ETS'lerde beklediği yanıt olan "Pollyanna" sözcüğünün bir hecesini söyleyerek öğrencilere ipucu (DIU as hint, Koshik, 2002) verdiği ve birden fazla öğrencinin bu sözcedeki eksik kısmı tamamlamak adına katılım gösterdiği (satır 10, 13, 16, 17) görülmektedir. Bu durum; öğretmenin ipucu olarak ETS kullanmasının bir örneği olmasının yanında ETS kullanımının öğrenci katılımını arttırdığının kanıtı olarak gösterilebilir. Bunun yanında, bir sözcüğün (iyimser) anlamını bulmaya yönelik pedagojik bir hedefin, bir 
çocuk kitabı kahramanı ile ilgili konuşmaya dönüşmesinin, dersin sosyal bilgiler dersi olduğunu göz önüne alındığında öğrenciler için önemli bir öğrenme fırsatına dönüştüğünü göstermektedir.

\section{Daha önceki konuşmaların genişletilmesi için kullanılan ETS'ler}

Günün ilk sosyal bilgiler dersidir. Öğretmen, "Kültür ögelerinin geçmişten bugüne değişerek taşındığına ilişkin yakın çevresinden kanıtlar gösterir." kazanımını edindirmek için gelenekler ve göreneklerle ilgili bir konuşma dizisi başlatmıştır. Bu konuda bir süre konuşulduktan sonra daha önce işlenen bir metne dair öğretmen öğrencilere sorular sorar. Dersin 27. dakikasında gerçekleşen konuşma dizisi Kesit 2'de gösterilmiştir.

\section{Kesit 2. Kına}

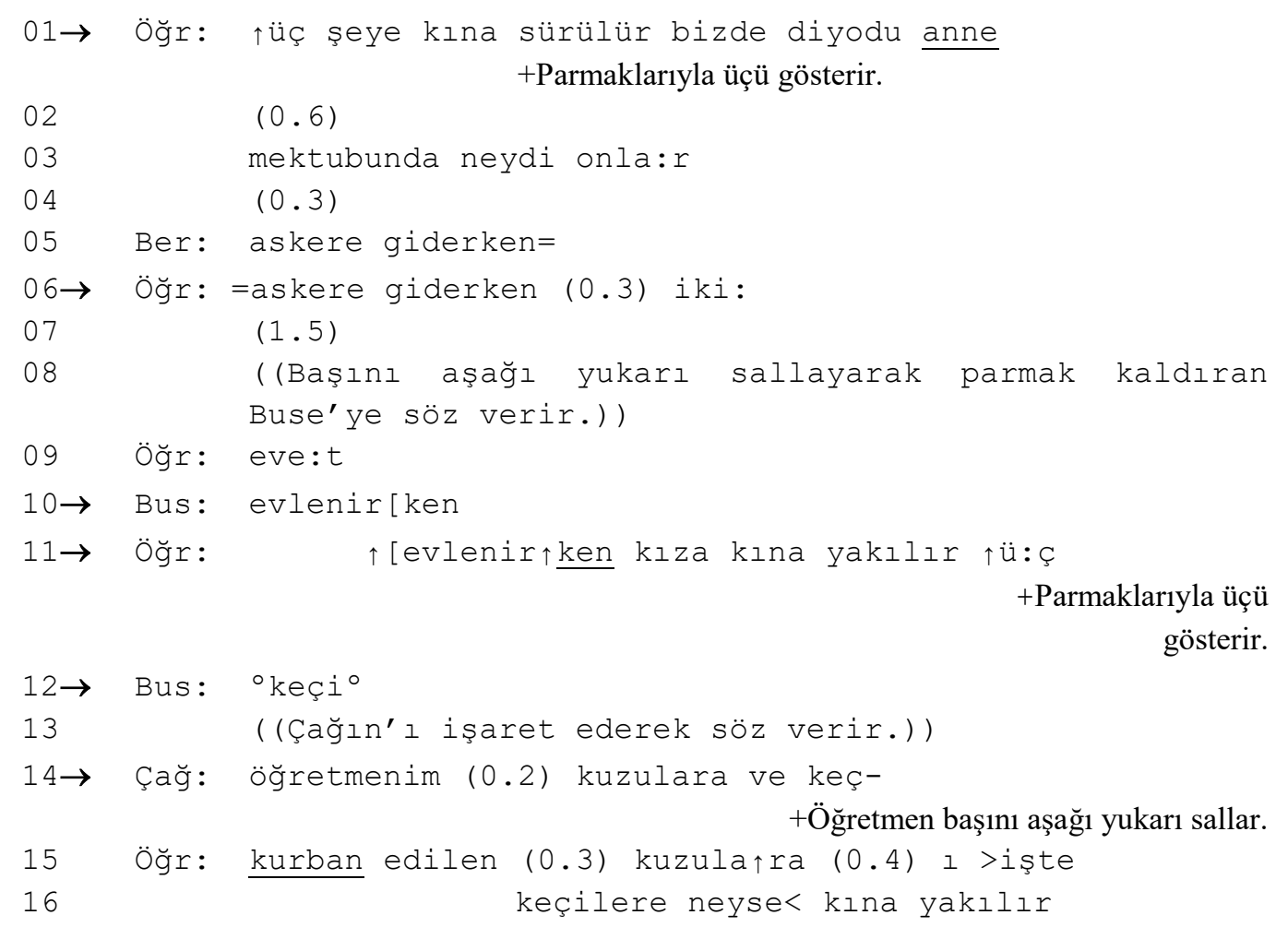

Kesit 2, satır 1'de öğretmenin metinden bazı bilgiler vererek hatırlatma yapmasıyla başlar. Öğretmen, "^üç şeye kına sürülür bizde diyodu anne" dedikten ve satır 2'de 0.6 saniyelik bir sessizlikten sonra söz sırasına devam ederek öğrencilere soru sorar. Öğretmen soruyu tüm sınıfa sormaktadır ve satır 5'te Ber adlı öğrenci öz seçim yaparak söz sırasını alır ve bir yanıt verir. Öğretmenin, Ber'den gelen yanıtı satır 6' da öğretmen-öğrenci ses yansıması (teacher-learner echo, Walsh, 2013) ile aynen tekrar ettiği görülmekte ve daha sonra “iki:" diyerek satır 1'de belirttiği üç yanıtın ikincisini öğrencilerden beklemektedir. Bu noktada öğrenci katkısını takiben kullanılan sayı aynı zamanda bir listeleme belirteci olarak da görülebilir ve bu özelliğiyle öğrenci katılımını devam ettirme amacına yönelik olduğu da iddia edilebilir. Öğretmenin satır 7'de 1.5 saniye boyunca öğrencilerden yanıt beklediği görülmektedir. Öğretmenin “iki” sözcügünün son hecesini uzatarak söyledikten sonra 1.5 saniye boyunca beklemesi, bu sözcügü eksik tasarlanmış sözce (ETS) olarak kullandığı ve daha önceki konuşmaların genişletilmesini (DIU that elicit an extension of prior talk, Koshik, 2002) yeğlediği gözlemlenebilir. Dolayısıyla hem listeleme belirteci hem de ETS olarak etkileşime 
dahil edilen "iki" ifadesi öğrenci katılımını sağlama hedefini bir kez daha ortaya çıkarmaktadır. Bekleme süresi boyunca öğrencilerden herhangi bir katkı gelmeyince, öğretmen Bus'a söz verir ve Bus'un satır 10'daki yanıtını satır 11'de kabul ederek tekrar eder (öğretmen-öğrenci ses yansımas1, Walsh, 2013). Bunu takiben yine “ $\uparrow \ddot{u}: c ̧$ ” diyerek yükselen tonlama ve hece uzatması ile hem listeye yeni bir belirteçle devam eder hem de eksik tasarlanmış sözceyi (ETS) bir kez daha aynı etkileşimsel hedefle kullanır. Öğretmenin beklediği yanıtı, satır 12'de Bus kısık sesle verir ancak öğretmen bu yanıta yönelim göstermez ve Çağ'a söz verir. Satır 14'te Çağ'ın verdiği yanıt henüz tamamlanmamış olmasına rağmen öğretmen söz sırasının başında doğru yanıtın gelmesiyle Çağın'ın sözünü keser. Satır 15 'te ise bu yanıtı yeniden düzenleyerek kesitin başında sorduğu sorunun yanıtlarını almış olur.

Kesit 2'de görülen öğrenci başlatımları temel olarak öğretmenin ETS ve listeleme belirteci kullanımı ile ortaya çıkmış ve bu kaynaklar bekleme süresi, öğretmen-öğrenci ses yansımaları, yükselen tonlama, ses uzatmaları gibi etkileşimsel kaynaklarla bir arada kullanılmıştır. Sonuç olarak, öğretmenin ETS kullanımı bir önceki kesitten farklı olarak; daha önceki konuşmaların genişletilmesi (DIU that elicit an extension of prior talk, Koshik, 2002) şeklinde ortaya çıkmış ve bu durum da öğrenci katılımını artıırmıştır. Bir önceki kesitte olduğu gibi öğretmen, sosyal bilgiler dersindeki bir kazanımı gerçekleştirmek adına öğrencilere daha önceki başka bir derste işlenmiş bir metnin içeriğine dair sorular sorması bu durumun öğrenciler için öğrenme firsatına dönüştüğünü göstermektedir.

\section{Daha önceki konuşmaların tekrarını almak için kullanılan ETS'ler}

Günün ikinci sosyal bilgiler dersidir. Öğretmen sözlü tarih yöntemini kullanırken dikkat edilmesi gereken önemli noktalardan birinin "randevu almak" olduğunu belirtmiştir. Bunun üzerine öğretmen, yaptığı bilimsel bir çalışmasında akademisyenlerden randevu alarak onlarla görüştügünden bahsetmiştir. Öğrencilerden birinin başlatım yaparak randevu alınan kişiye ulaşılamazsa ne olacağını sorması üzerine öğretmen böyle bir durumun olamayacağını belirtir ve bunun üzerine dersin 13. dakikasında ortaya çıkan konuşma dizisi Kesit 3'te gösterilmektedir.

\section{Kesit 3. Üniversite}

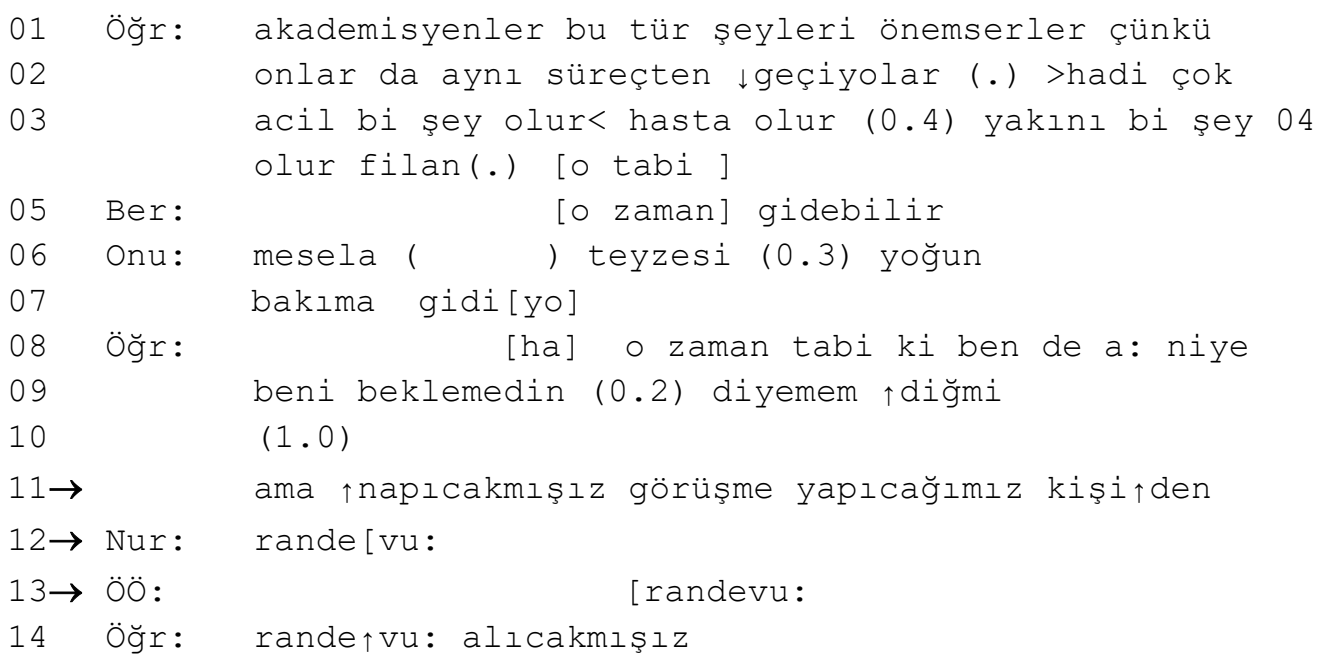


Kesit 3, öğretmenin satır 1'den satır 5'e kadar verdiği, randevu almak konusu kapsamında sunduğu akademisyenler üzerine örneklemesiyle başlar. Öğretmenin devam eden sözünün son kısmıyla Ber'in satır 5'teki sözü örtüşür. Daha sonra satır 6'da Onu adlı bir başka öğrenci öz seçim yaparak olası bir durumdan bahseder ve bu olasılığı bir örneklendirme ile sunar (mesela). Onu'nun katkısının öğretmenin satır 3'te sunduğu “yakını bi şey olur filan" görüşüne ilişkin bir örneklendirme olduğu görülmektedir (teyzesi (0.3) yoğun bakıma gidi [yo]). Bu söz sırasını takip eden satır 8'de öğretmen Onu'dan gelen bu katkıyı kabul eder, katkıya ilişkin bir değerlendirme yapar ve bu değerlendirmeyi de bir doğrulama isteği (request for confirmation) ile sonlandırır. Öğretmenin bu doğrulama isteğinden ( $\uparrow$ di ğmi) sonra satır 10'da 1 saniyelik bir sessizlik oluşur. Bu sessizlikten sonra satır 11'de öğretmen, öğrencilere, son hecede yükselen tonlama kullanarak bir soru yöneltir. Yükselen tonlama söz sırasının tamamlanışına ve soru formuna işaret etmektedir ve bir eksik tasarlanmış sözce kullanımı örneği daha oluşmuştur. Öğretmenin söz sırası bittikten sonra Nur'un satır 12'de öz seçim yaparak "rande [vu:" demesiyle birlikte son hece ile örtüşme içerisinde sinıftaki diğer öğrenciler koro halinde "[randevu:" yanıtını verirler. Öğretmen öğrencilerden gelen bu yanıtı "rande vu: alıcakmışız" şeklinde öğretmen-öğrenci ses yansıması (teacherlearner echo, Walsh, 2013) ile tekrar eder ve kesit sona erer.

Öğretmenin satır 11'de sınıftaki tüm öğrencilere bir soru yönelttiği ve bunu eksik bir sözce haline getirerek ETS şeklinde sunduğu görülmektedir. Öğretmen ETS'yi öğrenciden daha önceki konuşmaların tekrarını almak (DIU that elicit repetition of prior talk, Koshik, 2002) amacıyla kullanmış yani konuşma dizisinde daha önce vurgulanmış olan "randevu almak" eylemini öğrencilerden tekrar istemiştir. Öğretmenin bu sorusuna satır 12'de Nur adlı öğrencinin öz seçim yaparak yanıt verdiği, daha sonra ise sınıftaki tüm öğrencilerin koro halinde katılım gösterdiği görülmektedir. Bir öğrenci başlatımı ile başlayan ve diğer öğrencilerin başlatımları ile devam eden bu konuşma kesitinde öğretmenin başlatımlara yönelim göstererek kendi hayatından bir örnek verdiği ve bir mesleğe (akademisyenlik) ilişkin bilgi vermesiyle öğrenciler için öğrenme firsatlarının oluştuğu, bunu sağlayan temel etkileşim kaynağının ise ETS olduğu görülmektedir.

\section{ETS'nin yapılan eyleme devam edilmesinin teşviki için kullanılması}

Haftanın ilk sosyal bilgiler dersidir. Öğretmen "Duyguları ve düşünceleri arasındaki ilişkiyi fark etme" kazanımını edindirmek için öğrencilere "duygu ve düşünce aynı şey midir" diye bir soru yönelterek dersi başlatır. Bu soruya karşılık Bey takma adlı öğrenci öz seçim yaparak duygulara bazı örnekler verir. Bu öğrenci ve öğretmen arasındaki konuşma dizisi Kesit 4'te gösterilmiştir.

\section{Kesit 4. Duygu ve Düşünce}

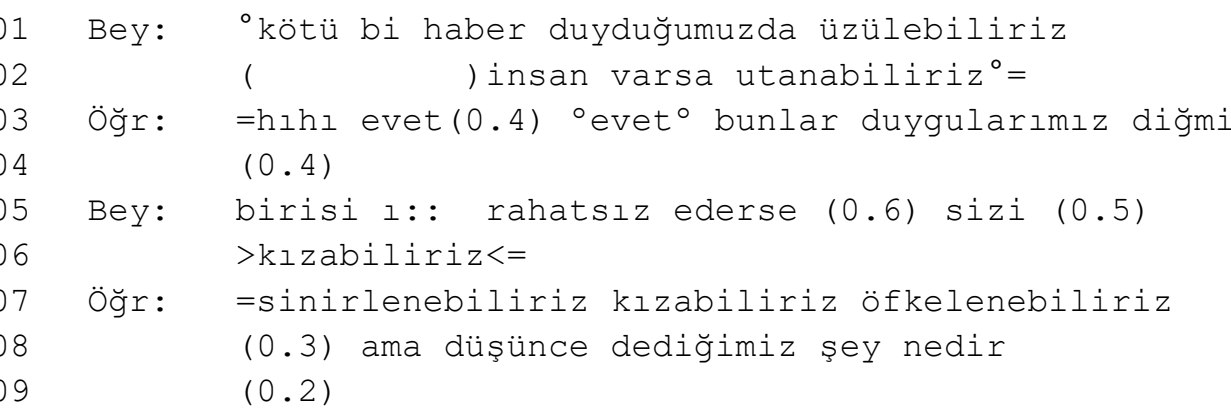




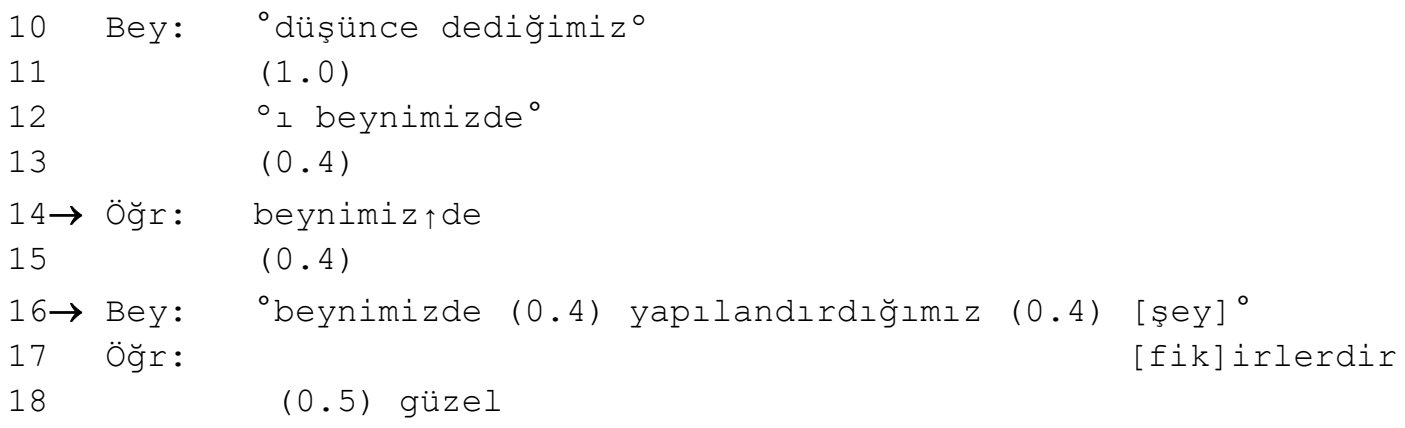

Kesit 4'te, Bey satır 1'de insan duygularına bir örnek verir ve öğretmen bu yanıtı kabul ederek satır 2'de "=hıhı evet $(0.4){ }^{\circ}$ evet ${ }^{\circ}$ bunlar duygularımız diğmi” diyerek söz sırasını bir doğrulama isteğinde (request for confirmation) bulunarak sonlandırır. Ancak öğrenci bunu onaylamak yerine satır 5 ile başlayan söz sırasında bir başka duyguya yönelik bir başka örnek verir. Satır 7'de öğretmen Bey'in bu yanıtını alarak yeniden düzenler (reformulation) ve "ama düşünce dediğimiz şey nedir" diye sorduktan sonra Bey satır 10'da daha kısık sesle ve söz sırası içinde 1 saniyelik sessizliklerle yanıt verir. Satır 14'te öğretmen öğrencinin söz sırası oluşturma birimini (SOB) tekrar edip (öğretmen-öğrenci ses yansımas1, Walsh, 2013) sözcüğün son hecesinde yükselen tonlama ve ardından 0.4'lük bir bekleyişle ETS kullandığ 1 görülmektedir. Öğretmenin ETS'yi eyleme devam etme konusunda teşvik (DIU prompts to continue an action, Koshik, 2002) amacıyla kullandığ görülmektedir. Diğer bir deyişle, öğretmen, öğrenciyi, cümlesini tamamlaması için teşvik etmektedir. Satır 16'da ise Bey ETS'yi “obeynimizde (0.4) yapılandırdığımız $(0.4) \quad[\text { şey }]^{\circ}$ ” diyerek bulamadığı kelime için önce (0.4)'lük bir süre boyunca uygun kelimeyi aramakta, ardından da bulamadığı kelime yerine "şey" kelimesini kullanmaktadır. Öğrencinin aradığ1 kelime için (0.4)'lük sessizlik oluştuğunu gören öğretmen öğrencinin “şey” kelimesiyle örtüşme içinde "fikirlerdir" kelimesini kullanmaktadır. Daha sonra ise öğrenciye "güzel" diyerek vurgulu olumlu değerlendirme (explicit positive assessment, Waring, 2008) yaptığı görülmektedir.

Kesit 4, Bey'den satır 1'de gelen yanıtla başlamakta ve Bey ile öğretmen arasında geçen bir diyalog halinde ilerlemektedir. Öğretmenin yeğlenen yanıtı alabilmek için ETS'yi farklı bir amaçla; eyleme devam etme konusunda teşvik olarak (DIU prompts to continue an action, Koshik, 2002) kullandığı ve bunun öğrenci katılımını arttırdığı görülmektedir. Öğretmen, öğrenci katılımını arttırmak için ETS'nin yanında farklı etkileşimsel kaynaklar da (öğretmenöğrenci ses yansımaları, doğrulamalar, bekleme süreleri gibi) kullandığı görülmektedir.

\section{Tartışma ve Sonuç}

Çalışmamız, eksik tasarlanmış sözcelerin (ETS), sosyal bilgiler sınıf içi etkileşimi kapsamında, öğretmen tarafından bir etkileşimsel kaynak olarak nasıl kullanıldığını ortaya koymuş ve öğretmenin bu kaynak aracılığıyla hem öğrenci başlatımlarına alan yarattığını hem de öğrenci katılımını gözlemlenebilir bir biçimde arttırdığını kanıtlar sunarak betimlemiştir. Koshik (2002) ile aynı doğrultuda, ETS'ler önceki öğrenmeyi hatırlatma (kesit 1), konuşmanın genişletilmesi (kesit 2), önceki konuşmaların tekrarını alma (kesit 3) ve eylemin devamına teşvik (kesit 4) amacıyla etkileşime girmiştir. ETS'ler aracılığıyla, öğretmen, öğrenci başlatımlarını ve 
katk1larını teşvik etmiş (Margutti, 2010; Sert \& Walsh, 2013; Waring, 2011), katılımı arttırmış ve sonuç olarak öğrenme firsatlarının ortaya çıkmasını sağlamıştır. Bu niteliğiyle ETS'lerin sosyal bilgiler sınıf içi etkileşiminde merkezi role sahip bir etkileşimsel kaynak olduğu gözlemlenmiştir.

Öğrencinin derse katılımını sağlamak, zorlu bir pedagojik görev olarak öğretmenin karşısında bulunmakta (Margutti, 2010; Sert \& Walsh, 2013; Waring, 2011, 2016; Watanabe, 2017) ve öğretmenlerin bunu başarmak üzere çeşitli kaynakları etkileşime dahil etmesi veya sınıf içi etkileşim aracılığıyla katılıma zemin hazırlaması gerekmektedir. Bunun etkili bir biçimde nasıl gerçekleştirilebileceği üzerine, eğitimin neredeyse bütün alanlarında teori temelli önerilerde (Evertson, 1994; Howard \& Henney, 1998; Rocca, 2010; Turner \& Patrick, 2004) bulunulmaktadır. Ancak, çalışmamızda ortaya çıktığı üzere, öğrenci katılımının sağlanması, etkileşimin mikro düzeyinde gerçekleştirilen etkileşimsel bir başarıdır (Sert, 2017; Waring, 2011). Çalışmamız, söz sıraları seviyesinde ETS'leri incelemiş ve ETS'lerin öğrenci katılımına doğrudan etkisini gözler önüne sermiştir. Bu temel bulguyla, varsayımsal öneriler yerine, anlık etkileşimsel başarıların incelenmesi yoluyla ortaya çıkarılacak sağlam temelli önerilerin öneminin de bir kez daha altı çizilmiştir. Bu kapsamda, çalışmamızın yöntemsel ve bilimsel altyapısını oluşturan, Konuşma Çözümlemesi araştırma yönteminin (Sert vd., 2015) önemi ve potansiyeli de bir kez daha belgelenmiştir. Bu yöntem, sosyal bilgiler alanına, araştırma yöntemleri açısından bir yenilik olarak çalışmamız aracılığıyla kazandırılmıştır.

Diğer bir taraftan, sosyal bilgiler sınıf içi etkileşimi üzerine daha önce herhangi bir çalışma yapılmamış olması da çalışmamızın ve bulguların önemine bir kez daha işaret etmektedir. Tek bir etkileşimsel kaynağın, sınıf içi etkileşimde oynadığı etkin rolün ortaya konması, aynı zamanda benzer çalışmalar aracılığıyla daha nice zengin etkileşimsel kaynakların keşfedilebileceği ve alana kazandırılabileceği anlamına da gelmektedir. Bu durum, KÇ’nin yöntemsel gücüne de ayrı bir örnek olarak gösterilebilir. Etkileşimin mikro detaylarına, söz sıraları, dizi, yeğleme düzeni ve onarım gibi etkileşimsel durumlara odaklanmayan çalışmaların, ETS'lerin ve benzeri kaynakların, etkileşimdeki rolünü tam anlamıyla yansıtması beklenemez. Bir etkileşimsel kaynağın beraberinde getirdiği sosyal eylemleri ve etkileşimsel başarıları anlayabilmek için, önceki söz sıralarında neler söylendiğini ve kullanılan kaynağın sonraki söz sıralarında ne tür katkılara aracılık ettiğini tespit edebilmek gereklidir. Bu türden bir yöntemsel ilerleyiş, KÇ’nin etkileşimi satır satır ve anbean çözümleyen analitik araçları ile mümkündür. $\mathrm{Bu}$ temelde, çalışmamızın sosyal bilgiler alanında yeni etkileşimsel çalışmalara örnek teşkil ederek zemin sağlayabilmesi ve çeşitli etkileşimsel kaynakların alana kazandırılması noktasında etkin rol oynaması bilimsel açıdan kritik öneme sahiptir.

Sınıf içi etkileşime odaklanan araştırmalar (Donato, 2000; Fagan, 2012; Garton, 2012; Jacknick, 2011; Mori, 2004; Pavlenko \& Lantolf, 2000; Rodriguez \& Wilstermann, 2018; Sert, 2015, 2017; Sfard, 1998; Walsh, 2002; Waring, 2011; Young \& Miller, 2004) bizim çalışmamamızda da olduğu gibi, öğrenme fırsatlarını da betimlemeye aracı olmaktadır. Sınıf içerisinde öğrencinin derse ve etkinliğe katılımının sağlanması kadar bu tür katılımların öğrenme fırsatına da dönüşmesi de merkezi bir role sahiptir. Çalışmamız, aynı zamanda ETS'ler aracılı̆̆ıyla, öğrenme firsatlarının nasıl ortaya çıkarılabileceğine de kanıt sunmuştur (Sert, 2017). Bu durum, hem sosyal bilgiler eğitimine hem de diğer eğitim alanlarına, öğrenme öğretme süreçlerinin etkileşimsel boyutunu anlamaya yönelik bir örnek sunmaktadır. Aynı zamanda öğrenme firsatlarının etkileşime dahil olduğu anların tespiti, bu anların sonraki etkileşim anlarında öğrenme çıtısı olarak etkileşime tekrar dahil olup olmayacağının 
anlaşılmasını da sağlayabilmektedir. Öğrenmeye, doğrudan etkileşimin içerisinden kanıt getirmek, bilişsel öğrenme yaklaşımlarının aksine, öğrenmenin doğasına gözlemlenebilir bir anlayış getirme olanağını da sunacaktır. $\mathrm{Bu}$ kapsamda, araştırmacıların, KÇ yöntemini kullanarak etkileşimsel kaynakların incelemesini yapmasının yanı sıra, öğrenme firsatları ve bu firsatların öğrenmeye dönüşme anlarını incelemeleri de çalışmamızın önerileri arasından yer almaktadır. Son olarak, çalışmamız öğretmen yetiştirme alanında da doğrudan kullanılabilir bir kaynak niteliği taşımaktadır. Çalışmamızın bulguları kullanılarak, öğrenci katılımını arttırma üzerine değerli bir etkileşimsel kaynak öğretmen adaylarına kazandırılmalı ve çeşitli yeni kaynakların KÇ araştırmalarıyla keşfedilmesine olanak sağlayan geniş kapsamlı projeler ve araştırmalarla öğretmen yetiştirme alanına katkılarda bulunulmalıdır.

\section{Teşekkür}

Bu çalışmanın bütünü olan doktora tezine yaptığı değerli katkılarından dolayı Dr. Olcay Sert'e teşekkürlerimizi sunarız. Üçüncü yazar, bu makalenin yazımı sürecinde TÜBİTAK, BİDEB2219 (1059B191601261) programı tarafından desteklenmiştir.

\section{Kaynakça}

Allwright, D. (2005). Developing principles for practitioner research: the case of exploratory practice. The Modern Language Journal, 89(3), 353-366.

Badem, F. (2018). Interactional resources for restoring understanding of teachers' instructions in an EFL classroom. Unpublished master thesis, Gazi University, Ankara.

Balaman, U. (2018). Embodied resources in a repetition activity in a preschool L2 classroom. NovitasROYAL (Research on Youth and Language), 12(1), 27-51.

Bozbiyık, M. (2017). The implementation of veo in an English language education context: A focus on teacher questioning practices. Unpublished master thesis, Hacettepe University, Ankara.

Can Daşkın, N. (2015). Shaping learner contributions in an EFL classroom: Implications for L2 classroom interactional competence. Classroom Discourse. 6(1), 33-56.

Daşkın, N. C. (2017). A conversation analytic investigation into L2 classroom interaction and informal formative assessment. ELT Research Journal, 6(1), 4-24.

Donato, R. (2000). Sociocultural contributions to understanding the foreign and second language classroom. In J. P. Lantolf (Ed.), Sociocultural theory and second language learning (pp. 27-50). New York: Oxford University Press.

Duran, D. (2017). Student-initiated questions in English as a medium of instruction classrooms in a Turkish higher education setting. Unpublished doctoral dissertation, Hacettepe University, Ankara.

Evertson, C. M. (1994). Classroom management for elementary teachers. Allyn \& Bacon, A Division of Simon \& Schuster, Inc., 160 Gould Street, Needham Heights, MA 02194.

Fagan, D. S. (2012). On language teachers' classroom practices: Bridging conversation analysis with language teacher education research. Teachers College, Columbia University Working Papers in TESOL and Applied Linguistics, 12(1), 35-37.

Garton, S. (2012). Speaking out of turn? Taking the initiative in teacher-fronted classroom interaction. Classroom Discourse, 3(1), 29-45.

Howard, J. R., \& Henney, A. L. (1998). Student participation and instructor gender in the mixed-age college classroom. The Journal of Higher Education, 69(4), 384-405.

Ingram, J., Briggs, M., \& Johnston-Wilder, P. (2011). Turn-taking in the mathematics classroom. In Proceedings of the Seventh Congress of the European Society for Research in Mathematics Education, 1325-1334. 
Jacknick, M. C. (2011). "But this is writing": Post-expansion in student-initiated sequences. NovitasROYAL (Research on Youth and Language),5(1), 39-54.

Jefferson, G. (2004). Glossary of transcript symbols with an introduction. In. G. Lerner (ed.) Conversation analysis, studies form first generation (pp. 13-34). John Benjamins.

Kardaş İşler, N. (2019). Illkokul sosyal bilgiler dersinde ögrenci başlatımları ve öğrenme firsatları: Konuşma çözümlemesi yaklaşımı. Yayınlanmamış doktora tezi, Hacettepe Üniversitesi, Ankara.

Kaya, G. (2017). Teacher talk and learner contributions in inquiry based science education: A conversation analytic examination. Unpublished doctoral dissertation, Hacettepe University, Ankara.

Koshik, I. (2002). Designedly incomplete utterances: A pedagogical practice for eliciting knowledge displays in error correction sequences. Research on language and social interaction, 35(3), 277-309.

Labov, W. (1972). Some principles of linguistic methodology. Language in society, 1(1), 97-120.

Lerner, G. H. (1995). Turn design and the organization of participation in instructional activities. Discourse Processes, 19(1), 111-131.

Margutti, P. (2010). On designedly incomplete utterances: What counts as learning for teachers and students in primary classroom interaction. Research on Language and Social Interaction, 43(4), 315-345.

Margutti, P., \& Drew, P. (2014). Positive evaluation of student answers in classroom instruction. Language and Education, 28(5), 436-458.

Mchoul, A. (1978). The organization of turns at formal talk in the classroom. Language in Society, 7 , 183-213.

Mehan, H. (1979). Learning lessons: Social organization in the classroom. Cambridge: Harvard University Press.

Milli Eğitim Bakanlığı (2005). İlköğretim sosyal bilgiler dersi 6 -7. sınıflar ögrretim programı ve kılavuzu. Ankara: MEB Talim ve Terbiye Kurulu Başkanlığı.

Mori, J. (2004). Negotiating sequential boundaries and learning opportunities: a case from a Japanese language classroom. The Modern Language Journal 88(4), 536-550.

Netz, H. (2016). Designedly incomplete utterances and student participation. Linguistics and education, $33,56-73$.

Newman, F. (1992). Student engagement and achievement in American secondary schools. New York: Teachers College Press.

Onursal, İ. (2003). Türkçe metinlerde bağdaş1klık ve tutarlılık. Günümüz dilbilim çalışmaları, 1, 121-132.

Paoletti, I., \& Fele, G. (2004). Order and disorder in the classroom. Pragmatics 14, 1(30), 69-85.

Patton, M. Q. (2014). Nitel araştırma ve değerlendirme yöntemleri. Çev. M. Bütün ve SB Demir). Ankara: PegemA Akademi.

Pavlenko, A., \& Lantolf, J. P. (2000). Second language learning as participation and the (re)construction of selves. In J. P. Lantolf (Ed), Sociocultural theory and second language learning (pp. 155-177). New York: Oxford University Press.

Rocca, K. A. (2010). Student participation in the college classroom: An extended multidisciplinary literature review. Communication education, 59(2), 185-213.

Rodriguez, J. B., \& Wilstermann, I. M. (2018). Learner initiative in the Spanish as a foreign language classroom: Implications for the interactional development. Hacettepe University Journal of Education, 33, 113-133.

Sacks, H., Schegloff, E. A., \& Jefferson, G. (1974). A simplest systematics for the organization of turntaking for conversation. Language, 50(4). 696-735.

Seedhouse, P. (2004). The interactional architecture of the language classroom: A conversation analysis perspective. Malden: Blackwell. 
Sert, O. (2015). Social interaction and L2 classroom discourse. Edinburgh: Edinburgh University Press.

Sert, O. (2016). Sınıf içi etkileşim ve yabancı dil öğretmeni yetiştirme. İçinde S. Akcan ve Y. Bayyurt (Ed.), Türkiye'deki yabancı dil eğitimi üzerine görüss ve düşünceler (ss. 14-30). İstanbul: Boğaziçi Üniversitesi Yayınevi.

Sert, O. (2017). Creating opportunities for L2 learning in a prediction activity. System, 70, 14-25.

Sert, O., Balaman, U., Can Daşkın, N., Büyükgüzel, S., \& Ergül, H. (2015). Konuşma çözümlemesi yöntemi. Mersin Üniversitesi Dil ve Edebiyat Dergisi 12(2), 1-43.

Sert, O., \& Walsh, S. (2013). The interactional management of claims of insufficient knowledge in English language classrooms. Language and Education, 27(6), 542-565.

Sfard, A. (1998). On two metaphors for learning and the dangers of choosing just one. Educational Researcher 27(2), 4-13.

Skovholt, K. (2018). Anatomy of a teacher-student feedback encounter. Teaching and Teacher Education, 69, 142-153.

Strauss, A., \& Corbin, J. (1990). Basics of qualitative research (Vol. 15). Newbury Park, CA: Sage.

Sumruk, H. (2018). Yabancı dil olarak Türkçe öğretiminde kelime öğretiminde etkileşimin konuşma çözümlemesi yöntemiyle incelenmesi: A2 örneği. Yayınlanmamış yüksek lisans tezi, Hacettepe Üniversitesi, Ankara.

Turner, J. C., \& Patrick, H. (2004). Motivational influences on student participation in classroom learning activities. Teachers College Record, 106(9), 1759-1785.

Walsh, S. (2002). Construction or obstruction: Teacher talk and learner involvement in the EFL classroom. Language Teaching Research, 6(1), 3-23.

Walsh, S. (2006). Investigating classroom discourse. Abingdon, Oxon New York: Routledge.

Walsh, S. (2013). Classroom discourse and teacher development, Edinburgh: Edinburgh University Press.

Waring, H. Z. (2008). Using explicit positive assessment in the language classroom: IRF, feedback, and learning opportunities. The Modern Language Journal, 92(4), 577-594.

Waring, H. Z. (2011). Learner initiatives and learning opportunities. Classroom Discourse, 2(2), 201-218.

Waring, H. Z. (2016). Theorizing pedagogical interaction: Insights from conversation analysis. New York: Routeldge.

Welton, A. D., \& Malian, J. T. (1999). Children and their world. Strategies for Teaching, H. Mifflin Company, USA.

Yıldırım, A. ve Şimşek, H. (2011). Sosyal bilimlerde nitel araştırma yöntemleri. Ankara: Seçkin Yayıncilik.

Young, R. F., \& Miller, E. R. (2004). Learning as changing participation: discourse roles in ESL writing conferences. Modern Language Journal, 88(4), 519-535.

Zemel, A., \& Koschmann, T. (2011). Pursuing a question: Reinitiating IRE sequences as a method of instruction. Journal of Pragmatics, 43(2), 475-488. 


\section{Extended Abstract}

\section{Introduction}

The social studies course is an important part of the primary school level education with various contributions to students in diverse fields such as citizenship, law, history, geography, economics, sociology, philosophy, anthropology, art history, and political science. Similar to many other courses, one of the key elements of this course is student participation. Student participation can be achieved by ensuring a positive classroom environment and creating opportunities for interaction (Sert, 2017). Therefore, for an understanding of student participation, classroom interaction in social studies courses should be closely examined. In terms of the methodological approach, while the first studies following this goal have largely focused on the observation and identification of the interaction using coding schemes, there has been an increasing interest in the use of conversation analysis as the research methodology (Sert, Balaman, Can Daşkın, Büyükgüzel, Ergül, 2015). Despite the major contributions of conversation analysis to the field of education by bringing insights into classroom discourse, there is no study to our knowledge that documents the interactional resources in social studies classrooms by focusing on the micro moments of classroom interaction. Therefore, we consider this a significant gap in literature and aim to contribute to the field with the first study in such contexts. Against this background, the purpose of this study is to describe the observable impact of designedly incomplete utterances (DIUs) on student participation at turns-at-talk and sequences of naturally occurring whole class interactions in a primary school fourth grade social studies course by using conversation analysis as the research methodology.

\section{Method}

Conversation Analysis emerged as a methodic tool for revealing the organizational patterns and systematicity of talk-in-interaction (cf. Sacks, Schegloff, Jefferson, 1974) from and within the fields of sociology and ethnomethodology. Conversation Analysis (CA) provides evidence to he members' methods for sense and meaning making by means of describing how participants understand each other minute by minute and turn by turn drawing on turn taking, sequence and preference organization, and repair. The data of the study was obtained from the social studies course at the fourth grade level of a public school in a classroom with 24 students. In order to protect the privacy of the participants, the pseudonyms were used in the transcription. In addition, the name of the school, the area it is in, or any personal information about the participants were changed to ensure privacy. Three video recorders were used during the data collection process. The entire dataset was transcribed in detail using the transcription conventions by Jefferson (2004).

\section{Results}

Our study has shown how designedly incomplete utterances (DIU) are used as an interactional resource by teachers in the context of social studies classroom interactions, which provides evidence that the teacher creates opportunities both for student initiations and student participation in an observable way. In the same direction as the study of Koshik (2002), DIUs are used as hint (Extract 1); DIUs elicit an extension of prior talk, (Extract 2); DIUs elicit 
repetition of prior talk (Extract 3); and DIUs prompt the continuation of an action (Extract 4). Thus, it was observed that DIU is an interactional resource with a central role in classroom interaction that is highly significant for creating opportunities for and increasing student participation.

\section{Discussion and Conclusion}

Providing the student participation is a challenging pedagogical task for teachers (Margutti, 2010; Sert \& Walsh, 2013; Waring, 2011, 2016; Watanabe, 2017) and they have to incorporate various resources to achieve this. It is deemed necessary to create opportunities for student participation through classroom interaction. Through the DIUs, the teacher encouraged student initiations and contributions (Margutti, 2010; Sert \& Walsh, 2013; Waring, 2011), increased student participation and thereby created learning opportunities. Thus, it was observed that DIU is an interactional resource with a central role in classroom interaction. We examined the DIUs at turns-at-talk and explore the direct impact of the DIUs on student participation. With this basic finding, the importance of providing grounded, situated, and data driven suggestions gained based on the examination of instantaneous interactional achievements, rather than building arguments based on hypothetical suggestions, has been strongly underlined. In this context, the importance and potential of the use of conversation analysis as a research methodology (Sert et. al., 2015), which constitutes the methodological and scientific structure of our study, has been once again documented. Our study has also showcased an innovative research methodology for the researchers in the field of social studies. Finally, we expect that by using the findings of our study, a valuable interactional resource on creating opportunities for student participation can be provided to the teacher candidates thus making a substantial contribution to the field of teacher training and highlighting the need for future projects and research for potential discoveries of various new sources by using Conversation Analysis. 


\section{Ek-1: Jefferson Çevriyazı Simgeleri}

Jefferson (2004) tarafından geliştirilen bu çevriyazı sisteminde kullanılan simgeler ve bunların anlamları aşağıdaki tabloda gösterilmiştir (Sert, Balaman, Can Daşkın, Büyükgüzel ve Ergül, 2015).

\begin{tabular}{|c|c|c|}
\hline Simge & Adı & Anlamı \\
\hline$[$ ] & Örtüşme & Örtüşmenin başlangıç [ ve bitiş ] noktalarını belirtir. \\
\hline$=$ & Mandallama & $\begin{array}{l}\text { Sözcenin boşluk bırakmadan bir önceki sözceyi takip etmesini } \\
\text { belirtir. }\end{array}$ \\
\hline$()$. & Anlık duraklama & $\begin{array}{l}0.2 \text { saniye ve altındaki anlı duraklamaları belirtir. Parantez } \\
\text { içerisinde nokta yerine sayı belirtilmesiyle de duraklamanın tam } \\
\text { olarak uzunluğu ifade edilir. }\end{array}$ \\
\hline$\downarrow$ & Düşen tonlama & Tonlamanın ya da sesin düşüşünü belirtir. \\
\hline$? \uparrow$ & Yükselen tonlama & Tonlamanın ya da sesin yükselişini belirtir. \\
\hline- & Kesme & Konuşmanın ani bir şekilde kesilmesini belirtir. \\
\hline$><$ & Hizlı konuşma & $\begin{array}{l}\text { Büyüktür simgesi ile küçüktür simgesi arasındaki çeviriler } \\
\text { konuşmanın normalden daha hızlı gerçekleştiğini belirtir. }\end{array}$ \\
\hline$<>$ & Yavaş konuşma & $\begin{array}{l}\text { Küçüktür simgesi ile büyüktür simgesi arasındaki çeviriler } \\
\text { konuşmanın normalden daha yavaş gerçekleştiğini belirtir. }\end{array}$ \\
\hline$\circ \circ$ & Düşük ses & $\begin{array}{l}\text { Derece simgeleri arasında çevrilen konuşmalar yumuşak, kısık veya } \\
\text { düşük bir ses kullanıldığını belirtir. }\end{array}$ \\
\hline $\mathrm{ABC}$ & Yüksek ses & $\begin{array}{l}\text { Büyük harflerle çevrilen konuşma bölümleri normalden oldukça } \\
\text { yüksek bir ses kullanıldığını belirtir. }\end{array}$ \\
\hline$\underline{\mathrm{abc}}$ & Vurgu & $\begin{array}{l}\text { Çevirinin altı çizili bölümleri konuşmada vurgu yapılan bölümleri } \\
\text { belirtir. }\end{array}$ \\
\hline$\because::$ & Uzatma & $\begin{array}{l}\text { Her bir iki nokta üst üste ilgili sesin } 0.2 \text { saniyelik uzatılmasını } \\
\text { belirtir. }\end{array}$ \\
\hline hhh & Nefes verme & $\begin{array}{l}\text { h harfleri duyulabilir nefes verme sesini belirtir ve sesin devam ettiği } \\
\text { oranda harf sayısı artabilir. }\end{array}$ \\
\hline .hh & Nefes alma & $\begin{array}{l}\text { Noktayı takip eden h harfi duyulabilir nefes alma sesini belirtir ve } \\
\text { sesin devam ettiği oranda harf sayısı artabilir. }\end{array}$ \\
\hline$($ ) & $\begin{array}{l}\text { Anlaşılmas1 } \\
\text { konuşma }\end{array}$ & $\begin{array}{l}\text { Çevriyazıyı oluşturan araştırmacının tam olarak anlayamadığ } \\
\text { konuşma bölümleri parantez içerisinde belirtilir. }\end{array}$ \\
\hline$(())$ & Çevriyazı yorumları & $\begin{array}{l}\text { Sözlü olarak ifade edilmeyen veya çevriyazıyı oluşturan kişinin } \\
\text { yorum eklemesini gerektiren konuşma bölümlerini belirtir. }\end{array}$ \\
\hline
\end{tabular}

